\title{
Analysis of the Limitation of Implementation of Act Against the Law and Force Majeure of Environmental Damage Due to Forest Fire by PT National Sago Prima Based on Legislation Number 32 Year 2009 Concerning Environmental Protection and Management
}

\author{
Nico Cassey ${ }^{1 *}$ Mella Ismelina Farma Rahayu ${ }^{1}$
}

\author{
${ }^{1}$ Faculty of Law, Universitas Tarumanagara, Grogol Petamburan, West Jakarta 11440, Indonesia \\ ${ }^{*}$ Corresponding author. Email: mellaismelina@yahoo.com
}

\begin{abstract}
One example of problems in environmental law that the author encountered is in the District Court Verdict Number 591/Pdt.G-LH/2015/PN.Jkt.Sel and the High Court Verdict Number 540/PDT/2017/PT.DKI which essentially contained fires forest that occurs in the Meranti Islands, which is an area belonging to PT National Sago Prima (PT NSP). In the legal considerations of the District Court judges, PT NSP was declared to have committed an illegal act which resulted in a forest fire because it was considered negligent in preventing and anticipating the forest fire. However, in the legal considerations of the High Court judges, the panel of judges has a different opinion, namely that the forest fire occurred not because of negligence by PT NSP but occurred because of a natural disaster. Then what is the basis for the judge's consideration in the limitation of enforcement of actions against the law and force majeure against environmental damage due to forest fires? Legal certainty has not been achieved due to differences in opinion regarding the status of forest fires because the Judges at the District Court and the High Court have different considerations. Apart from that, the permits required by PT NSP to run its business are also deemed non-existent, whereas in fact the permit is already owned, even though it is not yet under PT NSP's name.
\end{abstract}

\section{Keywords: Environmental Law, Act Against the Law, Force Majeur}

\section{INTRODUCTION}

\subsection{Background}

Indonesia has the potential of very rich natural resources and these natural resources are very much needed by the community to meet their daily needs. We as Indonesians should be grateful for the abundance of natural resources that we have. The main natural resources we need, such as water, land, and air that exist and are contained in this earth, which are a gift from God Almighty to every human being, especially all Indonesian people, therefore in utilizing these things must be done by the best possible in order to increase the prosperity of the Indonesian people. This has been mandated by the 1945 Constitution Article 33 paragraph (3) of the 1945 Constitution which reads, "The land and water and natural resources contained therein are controlled by the State and used for the greatest welfare of the people."
Indonesia has quite extensive forests which are one of the centers of biodiversity in the world, where Indonesia is the third of the seven countries called Megadiversity Country. In essence, forests are the embodiment of the five main elements consisting of earth, water, nature, air and sunlight. Therefore, utilizing the forest actually directs Panca Daya to a certain form at the place and time needed for the greatest possible physical and mental welfare and happiness of humans without neglecting the aspect of sustainability. Indonesian forests are home to thousands of floras and faunas, many of which are endemic to Indonesia.[1]

The environment as a gift and grace from God Almighty to the people and nation of Indonesia is a space for life in all its aspects and its incantations are in accordance with the insight of the archipelago. For this reason, it needs to be considered in managing the environment so that its sustainability can be maintained, not only used and utilized but also cared for in order to create a sustainable environmental utilization activity.[2] 
Environmental law is a set of regulations governing the protection and management of the environment, which is done to preserve the functions of the environment through measures of structuring, utilization, control, maintenance, supervision and law enforcement. Various legal regulations in which there are environmental laws contain legal principles that aim to regulate human behavior and actions in order to protect the environment from environmental damage so that its sustainability can be maintained. In this regard, regulations regarding the environment are regulated in Legislation Number 32 of 2009 concerning Environmental Protection and Management (UUPPLH)

In this day and age, many companies are both legal and non-legal entities that make plantation fields to be managed by the company itself. Basically, if a business sector (either with a legal entity or not) wants to run a business in the fields of agriculture, industry, trade and land transportation anywhere, it must have an environmental permit or a business license from the Decree of the Minister of Forestry of the Republic of Indonesia. Article 36 paragraph (1) UUPPLH states that, "Every business and / or activity that is obliged to have an Amdal or UKL-UPL must have an environmental permit". According to Article 1 paragraph (35) of the UUPPLH, "Environmental permits are permits given to every person conducting a business and / or activity that is obliged to have an amdal or UKL-UPL in the framework of environmental protection and management as a prerequisite for obtaining a business and / or activity license.", Then according to Article 1 paragraph (36) UUPPLH what is meant by business license is" Business and / or activity license is a license issued by a technical agency to conduct business and / or activities."

Every business activity is engaged in certain fields such as agriculture, industry, trade, and also land transportation which will basically have both positive and negative impacts on the surrounding environment, thus a license is required to anticipate the occurrence of undesirable things. Apart from having a business license, a company must also prepare an early warning system, adequate facilities and infrastructure from the start as a form of prevention against damage and the environment so that if the company violates and does not have an environmental permit it will be subject to sanctions in the form stated in Article 109 paragraph (1) UUPPLH, "Every person who carries out a business and / or activity without an environmental permit as referred to in Article 36 paragraph (1), shall be punished with imprisonment for a minimum of 1 (one) year and a maximum of 3 (three) years and a fine of at least Rp1.000.000.000,00 (one billion rupiah) and a maximum of Rp. 3.000.000.000,00 (three billion rupiah). " If it violates the article, it can be said to be an act against the law, because according to Article 1365 of the Civil Code, an act against the law is "Every act against the law, which incurs losses to another person, obliges the person who due to his wrongdoing to issue the loss, to compensate the loss. " The perpetrator who violates these rules needs to be charged with responsibility whose purpose is to protect other parties whose interests have been violated.

If the permit has been obtained, it is believed that the company's activities will not damage the environment so that the company can be said to be feasible and capable of running a plantation business with the conditions stipulated by law, then the plantation business activity cannot be considered an illegal act.

Act against the law in environmental law arise when there are problems in terms of environmental civil liability as regulated in article 1365 of the Civil Code and the application of the principle of strict liability (absolute responsibility), which is absolute responsibility for losses that occur due to environmental damage. In this case, it means that even though the business entity has provided compensation due to the environmental damage it has caused, the environmental conditions that have been damaged cannot be returned to its original condition, so it is very necessary to take preventive measures.

In the problems that occur in cases of illegal acts committed by PT National Sago Prima (PT NSP) so that the Ministry of Environment and Forestry of the Republic of Indonesia (KLHK) sued PT NSP because it was considered to have committed an illegal act. PT NSP is a company that carries out business activities in the field of sago plantations located in Meranti Islands Regency, Riau Province. According to the Ministry of Environment and Forestry, PT NSP carried out plantation activities which resulted in forest fires and caused losses. PT NSP is also considered not to have an Environmental Impact Analysis (AMDAL) because the AMDAL actually owns is on behalf of PT National Timber and Forest Products. PT NSP did not update the AMDAL so it could be said that PT NSP did not have an AMDAL. Furthermore, PT NSP does not have adequate facilities and infrastructure in controlling fire prevention (early warning system) so that fires occur over a long period of time and cause even greater damage. In this case, the panel of judges hearing the case has different opinions. According to the District Court judge, PT NSP was declared to have committed an illegal act because the forest fire occurred due to its negligence in anticipating the fire that occurred. On the other hand, the panel of judges at the High Court is of the opinion that the fire was not an act against the law due to negligence by PT NSP because the forest fire was a natural disaster.

KLHK has sued PT NSP in Verdict Number 591/Pdt.GLH/2015/PN.Jkt.Sel and then PT NSP filed an appeal in Verdict Number 540/PDT/2017/PT.DKI. There are dissent between Verdict Court judges and High Court judges. According to the judge at the South Jakarta District Court, the lawsuit filed was complete and correct so that the judge accepted the plaintiff's claim because the defendant had committed an illegal act, namely causing pollution and / or environmental damage as a result of the defendant's failure to anticipate forest damage in the event of a fire and must provide compensation in accordance with the provisions of the Environmental Law.

The opinion of the High Court judge stated that the forest fires that occurred were said to be force majeure. Force 
majeure in the law of engagement is one of the causes of non-performance in accordance with the agreement agreed upon by both parties. Force majeure in this case means a state of force which is usually aimed at an event that is beyond the reach of humans to be able to avoid the event, an event that is beyond human reach, which in this case means a natural disaster.

Based on the background description, the author is interested in studying the case comprehensively and putting it in the form of a thesis by taking the example of the case contained in Verdict Number 591/Pdt.GLH/2015/PN.Jkt.Sel and Verdict Number 540/PDT/2017/PT.DKI with the title "Analysis of the Limitation of Enforcement of Act Against The Law and Force Majeure of Environmental Damage Due to Forest Fires (Case Study of District Court Verdict Number 591/Pdt.G-LH/2015/PN.Jkt.Sel and Decisions High Court Verdict Number 540/PDT/2017/PT.DKI)".

\subsection{Problems}

Based on the background that the author has described, the author draws a problem, namely:

What are the Judges' Basic Considerations in Limitation of Enforcement of Act Against The Law and Force Majeure Against Environmental Damage Due to Forest Fires (Case Study of District Court Verdict Number 591 / Pdt.G-LH / 2015 / PN.Jkt.Sel and High Court Verdict Number 540 / PDT /2017/PT.DKI)?

\section{METHODS}

1. Nature of Research

Soerjono Soekanto and Sri Mamudji gave their opinion that normative legal research is legal research which is carried out by examining the "literature" material (secondary data).[3] The nature of the research used in this research is prescriptive which aims to provide arguments against the differences of opinion between the District Court and High Court decisions regarding forest fires.

2. Type of Research

The type of research that the author use in this study is in the form of Normative Law Research. Soerjono Soekanto and Sri Mamudji gave an opinion that normative legal research is legal research conducted by examining literature (secondary data) which includes several things, namely, research on legal principles, research on legal systematics, research on the level of vertical and horizontal synchronization, comparative law, history of law.[4]

3. Type of data

a. Primary data is obtained from statutory regulations, court decisions and official state documents.[5] In this research, the primary data is Legislation Number 32 of 2009.

b. Secondary data consisting of legal books or journals containing legal principles, doctrines, legal research results, legal dictionaries, and legal encyclopedias.

c. Non-legal data consisting of non-legal text books related to research such as general language dictionaries and general encyclopedias.[6]

4. Data Collection Techniques

Literature study of legal data, both primary legal data, secondary legal data, and non-legal data. The search for legal data can be done by literature review, literature study, listening, or being accessed via the internet.[7]

5. Data Analysis technique

The data analysis was done by case approach and statutory approach because the author uses statutory regulations for the main point for this research.

\section{DISCUSSION}

\subsection{Forest fires caused by PT NSP activities as Act Against the Law}

Acts against the law are regulated in Article 1365 of the Civil Code (KUHPerdata) which states, "Every act that violates the law and brings harm to others, obliges the person who caused the loss due to his mistake to compensate for the loss." However, Acts against the Law can also occur in Environmental Law, such as Article 1365 of the Criminal Code which is adopted in UUPPLH in Article 87 paragraph (1) which states, "Every person in charge of a business and / or activity commits an act that violates the law in the form of pollution and / or environmental damage that causes harm to other people or the environment is obliged to pay compensation and / or take certain actions ".

In this regard, that based on the definition of an illegal act in Article 1365 of the Criminal Code, an action can be said to be an act against the law if it meets the following elements:

1. There is an action that is done, either actively or passively. Active in the sense of committing an act that violates the law, while passive means not doing something that is an obligation which usually arises from a contract.

2. There are "acts against the law, actions that violate the subjective rights of others or that are contrary to the legal obligations of the parties concerned."

3. The existence of an error, the element of this error can be measured objectively and subjectively. Objective means that the error is proven in a way that if a normal human being can predict the result or risk, it will make him choose to do or not to do the action. Meanwhile, subjective means that the error can be proven whether someone who does it based on his expertise can predict the consequences of the actions he will do.

4. The incurred losses are divided into several types, namely material and immaterial losses. Material losses are losses that are actually suffered by the victim, while immaterial losses are losses that will be received 
at a later date or benefits that should have been obtained but because of the act the profit cannot be obtained.

5. There is a causal relationship between actions and losses.

In the case of forest fires that occurred in Meranti Islands, Riau Province which was caused by plantation activities carried out by PT NSP, it was considered an illegal act by the District Court judge because it was declared to have caused environmental pollution / or damage as a result of the defendant's negligence in anticipating forest damage in the event that fire. However, the High Court judge determined it as a force majeure by the judge because it was deemed to have occurred as a result of a natural disaster based on 2 evidence of the Meranti Islands Regent's decree which stated that the forest and / or land fires and the haze disaster that occurred were a natural disaster.

Forest fires that occur as a result of the plantation activities of PT NSP which are negligent in protecting its work area which is in a forest area, in other words it does not carry out forest protection. In Government Regulation Number 45 of 2004 concerning Forest Protection, Article 1 Paragraph (1) states that "Forest protection is an effort to prevent and limit damage to forests, forest areas and forest products, caused by human actions, livestock, fires, nature, pests and diseases, as well as defending and safeguarding the rights of the state, communities and individuals over forests, forest areas, forest products, investments and instruments related to forest management. " PT NSP as a company that carries out activities in the field of plantations in forest areas should have already carried out forest protection because in Article 8 Paragraph (2) of Government Regulation Number 45 of 2004 states that "forest protection for areas that have become the work area of the holder of the area utilization permit, utilization of environmental services, business permits for utilization of forest products, permits for collecting forest products, and holders of lease-to-use forest areas are implemented and become the responsibility of the permit holder concerned. "Furthermore, it is explained in Paragraph (4) that "forest protection" as referred to previously includes several things, namely:

1. Securing the working area concerning forests, forest areas and forest products including flora and fauna;

2. Preventing forest damage from human and livestock actions, forest fires, pests and diseases as well as natural forces;

3. Taking the first necessary action against forest security disturbances in the working area;

4. Reporting any incidents of legal violations in the working area at the nearest forestry agency;

5. Providing facilities and infrastructure as well as forest guard personnel as needed."

In addition to the definition of forest protection, there are also forest protection principles in Government Regulation Number 45 of 2004 Article 6 which states that "forest protection principles include:
1. Prevent and limit damage to forests, forest areas and forest products, caused by human actions, livestock, fires, natural forces, pests and diseases.

2. Defend and safeguard the rights of the state, society and individuals over forests, forest areas, forest products, investments and instruments related to forest management. "

Furthermore, it is explained in Article 20 Paragraph (1) that "to prevent and limit forest damage caused by fire as referred to in Article 6 letter a, control activities shall be carried out, which includes:

1. Prevention;

2. Blackout;

3. Handling after fire. "

An act that is done with an intentional element usually has the intention of the perpetrator to produce a certain result and the action is done consciously, this is what distinguishes it from the act committed with the element of negligence. Actions that are carried out with an element of negligence, with or without the intention of the perpetrator who did that is happened naturally without being planned in advance.

One important element of negligence is the failure to carry out the obligation of prudence by the perpetrator so that acts against the law occur with element of neglect. Apart from these elements, there is an important thing in negligence, namely the risk arising from an act that also causes losses.

Losses arising from illegal acts that can be proven to have been done intentionally, oblige the party that caused the loss to be responsible for the losses caused. On the other hand, if no evidence of intent is found, then the illegal act is said to have occurred as a result of his negligence, and the party who committed the illegal act must still be responsible for his negligence. Failure to carry out the precautionary obligation can be a reason to ask for legal responsibility on the grounds of an illegal act because the party that is supposed to carry out this obligation fails to carry it out. As for what is meant by the obligation of prudence in this case is by implementing an early warning system in the plantation activities of PT NSP. An early warning system is a system that every business actor in the plantation sector must have in order to control the prevention of forest fires and / or land in accordance with MOA 5/2018 concerning Opening and / or Processing of Land without Burning. As we know in the description of the position case, in carrying out its business activities, PT NSP does not yet have and implement the intended early warning system.

In accordance with the Regulation of the Minister of Agriculture of the Republic of Indonesia Number 5 of 2018 concerning the Opening and / or Processing of Plantation Land without Burning Article 12, plantation business actors are required to have fire control systems, facilities and infrastructure for plantation land. PT NSP as a plantation business actor, namely planters and / or plantation companies managing plantation businesses, must have this system. This is necessary so that the 
company can take responsibility for what will happen on its plantation land later, or at least be able to anticipate things that will happen in the form of prevention. There are many kinds of prevention systems, one of which is water management by building canal blocks and monitoring the water needed. The land that is owned by PT NSP is peatland so it is necessary to do this, but the fact is that the oil palm land it owns has been neglected and since 2016 there has been no maintenance anymore so the land has become sensitive and flammable.

\subsection{PT NSP has an AMDAL in the name of PT National Timber and Forest Product which has expired and has not been revised}

AMDAL stands for Environmental Impact Analysis, according to Government Regulation Number 27 Year 1999, AMDAL is a study of major and important impacts for the decision making of a planned business and / or activity on the environment required for the decisionmaking process regarding business operation and / or activities. AMDAL is regulated in 4 kinds of Government Regulations, namely:

1) Government Regulation Number 29 of 1986 concerning Environmental Impact Analysis

2) Government Regulation Number 51 of 1993 concerning Environmental Impact Analysis

3) Government Regulation Number 27 of 1999 concerning Environmental Impact Analysis

4) Government Regulation Number 27 of 2012 concerning Environmental Permits.

AMDAL is needed for a project that has not been running where the project is still in the planning stage, for projects that are still in the planning stage an AMDAL recommendation is needed which will be used to obtain environmental permits. AMDAL is needed for a feasibility study because it is listed in laws and government regulations. Besides, it is also used to protect the environment from industrial activities and other activities that can cause environmental damage.

AMDAL has several functions, including:

1) Assisting in the decision-making process regarding the environmental feasibility of the planned activities to be carried out

2) Provide input for the planning of environmental assessment and monitoring

3) As a condition for issuing a recommendation regarding a business license

4) As an environmental feasibility permit

5) As material for regional development planning

AMDAL has another term, namely an environmental feasibility study, a project or activity that will be carried out can obtain an AMDAL through several stages. The first is by analyzing 4 (four) documents regarding AMDAL, namely 4 (four) Government Regulations governing AMDAL which will later be tested by an AMDAL Consultant who has passed the AMDAL
Assessment Commission. Furthermore, the activity plan to be carried out is analysis to determine whether it is feasible or not. If the results of the analysis shows that the activity is environmentally feasible, an environmental permit will be granted which will then be a condition for issuing an AMDAL recommendation. After that, the environmental permit will be issued and if it has been approved then a business license will be issued. This is in accordance with UUPPLH Article 36 paragraph (1) which states that "Every business and / or activity that is required to have an AMDAL or UKL-UPL must have an environmental permit". Environmental permit According to Article 1 paragraph (35) UUPPLH, is a permit that is given to every person who carries out a business and / or activity that is obliged to have an amdal or UKL-UPL in the framework of environmental protection and management as a prerequisite for obtaining a business and / or activity license. Apart from having to have an environmental permit, every business also needs to have a business license, according to Article 1 paragraph (36) UUPPLH what is meant by a business license is "Business and / or activity license issued by a technical agency to conduct business and / or activities. "

AMDAL is one of the mandatory documents that must be owned by every business actor and / or activity before they carry out their activities, especially activities in forest areas which must have a Building Utilization Certificate issued by the local State Land Agency. In Legislation Number 32 Year 2009 Article 22 Paragraph (1) states that "every business and / or activity that has an important impact on the environment is required to have an AMDAL."

In Verdict Number 591 / Pdt.G-LH / 2015 / PN.Jkt.Sel, the Ministry of Environment and Forestry sued PT NSP for one thing because PT NSP was deemed not to have an AMDAL on behalf of PT NSP itself, so it was sued on this basis. PT NSP is considered to have carried out business activities without an AMDAL, whereas according to the Researcher's analysis, the AMDAL is still valid and is owned by PT NSP because both PT National Timber and Forest Products and PT NSP have not had fundamental changes in their business fields and the affected environmental features are not changed. A company must revise the AMDAL or create a new AMDAL if there are changes in fundamental areas, namely its business, environmental features, and raw materials. So, in fact, the KLHK lawsuit against PT NSP regarding the absence of an AMDAL is a false claim.

If a business does not have an environmental permit which is actually obliged to AMDAL or UKL-UPL, it will be subject to criminal sanctions as regulated in Article 109 paragraph (1) of Legislation Number 32 Year 2009, namely that "Anyone who carries out a business and / or activity without a permit environment as referred to in Article 36 paragraph (1) will be sentenced to imprisonment for a minimum of 1 (one) year and a maximum of 3 (three) years and a fine of at least IDR $1,000,000,000.00$ (one billion rupiah) and a maximum of IDR 3,000 .000,000.00 (three billion rupiah) ". In addition to business activities that will be subject to fines if they do 
not have an AMDAL, the official issuing the business license will also be subject to sanctions in accordance with Article 111 paragraph (2) of Legislation Number 32 of 2009 which states that "Officials issuing business licenses and / or activities that issue licenses Business and / or activities without an environmental permit as referred to in Article 40 paragraph (1) shall be punished with imprisonment of up to 3 (three) years and a maximum fine of Rp. 3,000,000,000.00 (three billion rupiah)".

\subsection{The responsibility of PT NSP for forest fires}

According to Government Regulation Number 4 of 2001 concerning Control of Environmental Damage and / or Pollution Associated with Forest and / or Land Fires, Article 13 states that "Every person in charge of a business whose business can have a major and important impact on environmental damage and or pollution related to forest and / or land fires are required to prevent forest and / or land fires in the business location". PT NSP in this case as the person in charge of the business can prevent forest and / or land fires in its business locations by having the means and infrastructure for preventing forest and / or land fires, or what has previously been mentioned, namely an early warning system which consists of a detection system, early education, forest fire prevention tools, standard operating procedures to prevent fire, organizational tools, to training for regular forest fire management.

The responsibility of the person in charge of this business is further regulated in Article 51 which states that the person in charge of the business is absolutely responsible for the losses incurred and also has an obligation to pay compensation directly when environmental damage occurs, in this case a forest fire. In addition, this responsibility is also regulated in Legislation Number 32 of 2009 Article 87 paragraph (1) which states that "Every person in charge of a business and / or activity that commits an illegal act in the form of pollution and / or damage to the environment that causes loss. to other people or the environment must pay compensation and / or take certain actions. "Certain actions referred to in this article are to restore conditions on land that has been affected by pollution or land destruction. The losses caused by these forest fires are not only economic losses, but also ecological losses.

\subsection{Dissent between District Court and High Court judges regarding the status of forest fires}

Forest fires that occurred due to plantation activities carried out by PT NSP in its working area occurred within a long period of time. There are differences in determining the status of the forest fires, as previously discussed, namely that this case has been tried at the District Court and High Court levels where there are differences of opinion from the judges at the District Court and High Court levels. In District Court Verdict Number 591 /
Pdt.G-LH / 2015 / PN.Jkt.Sel, the panel of judges argued that the fire that occurred was an illegal act committed by the defendant, namely PT NSP, which was negligent in preventing and anticipating the forest fire. Furthermore, in the High Court Verdict Number 540 / PDT / 2017 / PT.DKI, the panel of judges had a different opinion, namely that the forest fires that occurred in the PT NSP work area were caused by natural disasters not due to negligence of PT NSP. According to the panel of judges, based on the available evidence, namely the Meranti Islands Regent's decree, the forest fire that occurred was declared a natural disaster. Therefore, legally, compensation for environmental damage due to the fire that occurred cannot be held responsible to PT NSP. From the two decisions, it can be seen that there is a clear difference between the opinions of the judges at the District Court and the High Court. This difference of opinions has resulted in legal uncertainty in determining the status of the forest fires. To be able to create legal certainty in this case, it is necessary to compare the two opinions and then determine which one opinion is more appropriate in terms of the reasons and considerations given so that the community can have behavioral guidelines later.

\section{CONCLUSION}

Based on the results of the studies that have been carried out and based on the theories that have been put forward, the author can draw a conclusion, namely;

1. Forest fires that occur due to planation activities carried out by PT NSP are an act against the law because they fulfill the elements of an illegal act, where this act violates Legislation Number 32 of 2009. Besides, there is also element of error in this incident as well as any losses committed by PT NSP so that there is a causal relationship between the act and the loss. PT NSP has proven to be negligent in protecting its working area which is in the forest area so that is unable to prevent and anticipate fires so that they do not have a big impact. This is because the early warning system owned by PT NSP is not going well.

2. PT NSP who was sued by the Ministry of Environment and Forestry for not having an AMDAL is the right thing because PT NSP is actually still using the AMDAL that belongs to PT National Timber and Forest Product. Even though it is still in the name of a company that was previously considered to have AMDAL, it can be said that the AMDAL is owned by PT NSP. Revisions to the AMDAL must be carried out if there are fundamental changes in the business sector of the company and the environmental conditions affected by its business activities have not changed, but if there is a company change, it is necessary to make a new AMDAL especially if the validity period of the AMDAL has expired. In addition, it is impossible for a company to establish if it does not have an AMDAL in advance, because AMDAL is made at the beginning of the planning and formation of the company. 
3. PT NSP is responsible for forest fires that occur due to proven wrongdoing, and must provide compensations for losses resulting from these actions. This is because PT NSP is unable to prevent forest fires in its working area so that forest fires destroy large and wide areas of land. Supposedly, with a good early warning system, these forest fires could be resolved quickly so that the spread of the flames was not so wide. The compensation that must be given is not only limited to material compensation but also compensation for ecological damage by carrying out certain activities to restore the environment that has already been damaged.

\section{REFERENCES}

[1] Koesnadi Hardjasoemantri, Hukum Perlindungan Lingkungan, Konservasi Sumber Daya Alam Hayati dan Ekosistemnya (Yogyakarta; Gadjah Mada University Press, 1991), 3.

[2] Siswanto Sunarso, Hukum Pidana Lingkungan Hidup dan Strategi Penyelesaian Sengketa (Jakarta: PT Rineka Cipta, 2005), 1.

[3] Mukti Fajar ND dan Yulianto Achmad, Dualisme Penelitian Hukum Normatif dan Empiris, Cetakan Ke-

1. (Yogyakarta: Pustaka Belajar, 2010), 34.

[4] Mukti Fajar ND dan Yulianto Achmad, Dualisme Penelitian Hukum Normatif dan Empiris, Cetakan Ke1. (Yogyakarta: Pustaka Belajar, 2010), 35.

[5] Mukti Fajar ND dan Yulianto Achmad, Dualisme Penelitian Hukum Normatif dan Empiris, Cetakan Ke1. (Yogyakarta: Pustaka Belajar, 2010), 42-43.

[6] Mukti Fajar ND dan Yulianto Achmad, Dualisme Penelitian Hukum Normatif dan Empiris, Cetakan Ke1. (Yogyakarta: Pustaka Belajar, 2010), 43.

[7] Mukti Fajar ND dan Yulianto Achmad, Dualisme Penelitian Hukum Normatif dan Empiris, Cetakan Ke1. (Yogyakarta: Pustaka Belajar, 2010), 160. 